\title{
The Effect of Reward and Punishment, Teacher Readiness, Utilization of Information and Communication Technology on Student Achievement
}

\author{
Irham Abdul Haris ${ }^{1}$, Nyayu Khodijah ${ }^{2}$, Abdurrahmansyah ${ }^{3}$
}

DOI: $10.35445 /$ alishlah.v13i3.734

\begin{tabular}{l} 
Article Info \\
\hline Keywords: \\
Reward and \\
punishment, \\
Teacher readiness, \\
Information and \\
communication \\
technology, \\
Learning achievement
\end{tabular}

Kata kunci:

Reward and punishment, Kesiapan guru, Teknologi informasi dan komunikasi, Prestasi belajar

\begin{abstract}
The study aimed to determine the effect of the reward and punishment method, teacher readiness, and the use of information and communication technology on student achievement in the Akidah Akhlak subject at Madrasah Aliyah Hidayatul Mubtadiin Jati Agung, South Lampung Regency. The research was quantitative. The population in the study was 235 students with a random sampling technique. The sample used was 235 students. The data collection method used was a questionnaire. The method of data analysis was done by descriptive analysis and path analysis. The study showed that the reward and punishment method positively affected student learning achievement by 19.20\%. Second, teacher readiness positively affected student achievement by 26.5\%. Third, information and communication technology positively affected student achievement by $29.1 \%$. Fourth, the method of reward and punishment, teacher readiness, and the use of information and communication technology simultaneously positively affected student learning achievement by $36.7 \%$. Thus, teachers were expected to use the reward and punishment method, prepare themselves, and utilize information and communication technology to affect student achievement positively.
\end{abstract}

\begin{abstract}
Abstrak
Penelitian ini bertujuan untuk mengetahui pengaruh metode reward and punishment, kesiapan guru dan pemanfaatan teknologi informasi dan komunikasi terhadap prestasi belajar siswa pada mata pelajaran Akidah Akhlak di Madrasah Aliyah Hidayatul Mubtadiin Jati Agung Kabupaten Lampung Selatan. Penelitian ini merupakan penelitian kuantitatif. Populasi dalam penelitian ini berjumlah 235 siswa, dengan teknik random sampling maka sampel yang digunakan sebanyak 235 siswa. Metode pengumpulan data yang digunakan adalah kuesioner. Metode analisis data dilakukan dengan analisis deskriptif dan analisis jalur (path analysis). Penelitian ini menunjukkan bahwa pertama, metode reward and punishment berpengaruh positif terhadap prestasi belajar siswa sebesar 19,20\%. Kedua, kesiapan guru berpengaruh positif terhadap prestasi belajar siswa sebesar 26,5\%. Ketiga, pemanfaatan teknologi informasi dan komunikasi berpengaruh positif terhadap prestasi
\end{abstract}

\footnotetext{
${ }^{1}$ IAI An Nur Lampung, Indonesia

Email: irhamabdulhariso@gmail.com

${ }^{2}$ UIN Raden Fatah Palembang, Indonesia

Email: nyayukhodijah_uin@radenfatah.ac.id

${ }^{3}$ UIN Raden Fatah Palembang, Indonesia

Email: abdurrahmansyah_uin@radenfatah.ac.id
} 
belajar siswa sebesar 29,1\%. Keempat, metode reward and punishment, kesiapan guru, pemanfaatan teknologi informasi dan komunikasi secara simultan berpengaruh positif terhadap prestasi belajar siswa sebesar $36,7 \%$. Dengan demikian guru diharapkan dapat menggunakan metode reward and punishment, melakukan persiapan diri, dan memanfaatkan teknologi informasi dan komunikasi karena berpengaruh positif terhadap prestasi belajar siswa.

\section{INTRODUCTION}

Humans have always relied on education as an essential part of their lives. An essential part of the Indonesian nation's dream was to improve the quality of human life and the Indonesian people and increase people's productivity and competitiveness in international markets so that the Indonesian nation could advance and rise alongside other Asian nations (Muliastrini, 2019). People's knowledge, attitudes, and skills can be improved through education. Education is a significant factor in shaping people's personalities (Abbas et al., 2017; Shane, 1984; Yayan Alpian et al., 2019). People's hopes for education must be met by the government's commitment to equity and educational advancement, as mandated by the Education Reform and Improvement Act of 2001. (Syah, 2012).

All components in educational institutions must work together in achieving educational goals such as learning activities, between teachers and students must collaborate so that learning objectives can be achieved. Learning achievement was satisfactory. Teachers played an essential role in school learning, including managing classes, motivating students, developing student potential, and others (Alawiyah, 2013; Minsih, 2018; Sutikno, 2007; Zein, 2016). Teachers who need to achieve learning goals and parents, students, curriculum, learning media, learning methods, and others.

Teachers had dual roles in the learning process, namely teaching and as class managers (Buchari, 2018; Ningsih, 2019). The teacher was previously prepared to learn administration, learning media, learning methods, information and communication technology (ICT), and others. Everything needed to be prepared to convey the material well to students. An effective classroom management strategy requires teachers to think about the needs of students and the content they will be teaching while also devising strategies to deal with any obstacles or challenges that may arise. This ensures that students can focus on their learning and progress through the process. Teaching and learning can still run, and the predetermined learning objectives can be achieved (Bali et al., 2021; Ningsih, 2019). For learning objectives to be completed, one of which was student achievement, teachers need to utilize all available resources.

Nasution (2009) explained that knowing whether education was quality or not was by looking at student achievement. Learning achievement is the perfection that a person achieves in thinking, feeling, and doing. Learning achievement was perfect if it met three aspects, namely cognitive, affective and psychomotor. Otherwise, it was said to be unsatisfactory if a person had not been able Student achievement was affected by two factors, namely internal and external factors. Internal factors included physical health, disability, intelligence, attention, interests, talents, learning motivation, readiness, student attitudes, and fatigue. Another internal factor that affected student achievement was the EQ (Emotional Quotient) factor (Slameto, 2010). Furthermore, Goleman (2004) revealed that humans had another essential potential: emotional intelligence.

Several studies that had been conducted previously include increasing student activity and learning outcomes through the provision of rewards and punishments (Sutardi, 2020). The application of reward and punishment methods to increase student motivation and learning outcomes (Isnaini, 2018; Nilam, 2020), the effect of reward and punishment for interest in learning (Aidillah, 2018), Effect of Application of Information and Communication Technology (ICT) on Learning Achievement (Kurniawan, 2019; Priatna, 2011; Yusri, 2016), Effect of Teacher Readiness on Utilization of E-Learning (Iptian, 2019). Based on the description above, no research had been found on the effect of the reward and punishment method, teacher readiness, and the use of information and communication technology on student learning achievement. Therefore, the purpose of the study was to determine how much effect the reward and punishment method, teacher 
readiness, and the use of information and communication technology had on student learning achievement.

\section{METHOD}

The type of research was quantitative research. A questionnaire did the data collection. The population in the study were all students of Madrasah Aliyah Hidayatul Mubtadiin Jati Agung, South Lampung Regency, totaling 235 students. With random sampling technique, the sample was taken as many as 143 students or as much as $5 \%$ of the population. The questionnaire instrument before being used was tested for validity with the SPSS version 18.0 application program and reliability with an alpha scale (Alpha Cronbach). Then the data were analyzed using descriptive analysis and path analysis.

\section{FINDINGS AND DISCUSSION}

\section{Variable Data Description}

a. Learning achievement data

Table 1. Learning achievement

\begin{tabular}{lc}
\hline \multicolumn{1}{c}{ Description } & Score \\
\hline Mean & 160,042 \\
Median & 158,00 \\
Modus & 157 \\
Std. Deviation & 14,725 \\
\hline
\end{tabular}

From table 1, it can be measured that the student achievement variable scores varied from the lowest score of 128 to a maximum of 197. Based on basic statistical calculations, the numbers obtained were: mean $=160.042$, median $=158.00$, modus $=157$, standard deviation 14.725, class range $=69$, class number $=8$, and class length $=9$. This calculation showed that the mean and median were not too much different. This indicated that the student achievement variable scores tended to be normally distributed.

b. Reward and punishment method data

\section{Table 2. Reward and punishment method}

\begin{tabular}{lc}
\hline \multicolumn{1}{r}{ Description } & Score \\
\hline Mean & 160,042 \\
Median & 158,00 \\
Modus & 157 \\
Std. Deviation & 14,725 \\
\hline
\end{tabular}

From table 2, it can be seen that the teacher's reward and variable punishment score $\left(\mathrm{X}_{1}\right)$ on students varied from the lowest score of 65 to a maximum score of 179 . Based on basic statistical calculations, the numbers obtained were: mean $=128.5$, media $=125$, modus $=121$, standard deviation $=24.42$, class range $=114$, number of classes $=8$, and class length $=15$. This calculation showed that the mean and median were not too much different. This indicated that the score of the teacher's reward and punishment variable $\left(\mathrm{X}_{1}\right)$ to students tended to be normally distributed.

c. Teacher readiness data

Table 3. Teacher readiness

\begin{tabular}{lc}
\hline \multicolumn{1}{c}{ Description } & Score \\
\hline Mean & 143,75 \\
Median & 143 \\
Modus & 139 \\
Std. Deviation & 14,52 \\
\hline
\end{tabular}


From table 3, it can be seen that the teacher readiness variable score $\left(\mathrm{X}_{2}\right)$ of Akidah Akhlak varied from the lowest score of 107 to a maximum score of 177 . Based on basic statistical calculations, the following numbers were obtained: mean $=143.75$, median $=143$, modus $=139$, standard deviation $=14.52$, class range $=70$, number of classes $=8$, and class length $=9$. This calculation showed that the mean and median were not too much different. This indicated that the score of the teacher readiness variable was normally distributed.

d. Information and communication technology utilization data

Table 4. Utilization of information and communication technology

\begin{tabular}{lc}
\hline \multicolumn{1}{c}{ Description } & Score \\
\hline Mean & $151,5^{2}$ \\
Median & 150 \\
Modus & 158 \\
Std. Deviation & 13,879 \\
\hline
\end{tabular}

From table 4, it can be seen that the variable score of the use of teacher information and communication technology $\left(\mathrm{X}_{3}\right)$ of Akidah Akhlak varied from the lowest score of 119 to a maximum score of 188. Based on basic statistical calculations, the numbers obtained were mean $=151.52$, median $=150$, modus $=158$, standard deviation $=13,879$, class range $=69$, number of classes $=8$, and class length $=9$. This calculation showed that the mean and median were not much different. This indicated that teachers' variable score of information and communication technology was normally distributed.

\section{Normality Test}

Table 5. Normality test

\begin{tabular}{clccc}
\hline No & \multicolumn{1}{c}{ Variables } & Sig. KS & $a=0,05$ & Description \\
\hline 1 & Learning Achievement $(\mathrm{Y})$ & 0,154 & 0,05 & Normal \\
2 & Reward \& Punishment $\left(\mathrm{X}_{1}\right)$ & 0,150 & 0,05 & Normal \\
3 & Teacher Readiness $\left(\mathrm{X}_{2}\right)$ & 0,064 & 0,05 & Normal \\
4 & Utilization of ICT $\left(\mathrm{X}_{3}\right)$ & 0,140 & 0,05 & Normal \\
\hline
\end{tabular}

Based on table 5 showed that the data for the four research variables came from a normally distributed population. Thus the path analysis technique can be used to test hypotheses about the effect between research variables.

\section{Hypothesis Testing}

Table 6. Analysis results of correlation coefficient regression coefficient and path coefficients of $X_{1}, X_{2}, X_{3}$ variables to $Y$

\begin{tabular}{ccccc}
\hline Variables & $\begin{array}{c}\text { Correlation } \\
\text { Coefficient }\end{array}$ & $\begin{array}{c}\text { Regression } \\
\text { Coefficient }\end{array}$ & $\begin{array}{c}\text { Path } \\
\text { Coefficients }\end{array}$ & Significant \\
\hline $\mathrm{X}_{1}-\mathrm{Y}$ & 0,438 & 0,264 & 0,273 & 0,000 \\
$\mathrm{X}_{2}-\mathrm{Y}$ & 0,515 & 0,522 & 0,061 & 0,000 \\
$\mathrm{X}_{3}-\mathrm{Y}$ & 0,539 & 0,572 & 0,398 & 0,000 \\
$\mathrm{X}_{(123)}-\mathrm{Y}$ & 0,604 & 0,645 & 1,649 & 0,000 \\
\hline
\end{tabular}

First, there was a direct positive and significant effect of the teacher's reward and punishment method on students' learning outcomes, which meant that the higher the significant score of the reward and punishment method, the higher the student's learning achievement, and vice versa. The strength of the correlation between reward and punishment with student achievement was shown by the correlation coefficient $\mathrm{r}_{\mathrm{yx} 1}$ of 0.438 and the closeness of the relationship was indicated by the coefficient of determinant $\mathrm{r}_{\mathrm{yx} 1}^{2}$ of 0.192 , which meant that $19.20 \%$ increase in student achievement was carried out by variations in the score of reward and punishment with the line equation $\mathrm{Y}=126.094+0.26 \mathrm{X}_{1}$, which meant that if the $\mathrm{X}_{1}$ score was increased by one unit, the $\mathrm{Y}$ 
score increases by 0.26 at the constant 126,094. Furthermore, based on the calculation of the path coefficient, for $\mathrm{Y}$ and $\mathrm{X}_{1}\left(\mathrm{P}_{\mathrm{yx} 1}\right) 0.273$ was greater than 0.05 , it can be concluded that the path coefficient between $\mathrm{Y}$ and $\mathrm{X}_{1}$ was significant or meaningful.

Second, there was a direct positive and significant effect of teacher readiness on student achievement, which meant that the higher the teacher's readiness to teach, the higher the student achievement scores, and vice versa. The strength of the correlation between teacher readiness and student achievement was shown by the $\mathrm{r}_{\mathrm{yx} 2}$ correlation coefficient of 0.515 and the closeness of the relationship shown by the coefficient of determination $\mathrm{r}^{2}{ }_{\mathrm{yx} 2}$ of 0.265 , which meant that $26.50 \%$ of the increase in student achievement was affected or carried out by variations in teacher readiness in teaching with the regression equation simple linear $\mathrm{Y}=84.970+0.522 \mathrm{X}_{2}$, which meant that if the $\mathrm{X}_{2}$ score was increased by one unit, the $\mathrm{Y}$ score increases by 0.522 at the constant 84.970 . Based on the results of the calculation of the path analysis between $\mathrm{Y}$ and $\mathrm{X}_{2}$, it was obtained for Pyx2 $=0.061$ which meant it was greater than 0.05. It was also concluded that the path coefficient between $\mathrm{Y}$ and X2 was also obtained as significant or significant.

Third, there was a direct positive and significant effect of the use of information and communication technology by teachers on student achievement, which meant that the higher the score on the use of information and communication technology by the teacher, the higher the student achievement score and vice versa. The large effect of the use of information and communication technology on student learning achievement was shown by the correlation coefficient $r_{\mathrm{y} 3}$ of 0.539 and the closeness of the effect or relationship was indicated by the coefficient of determination $\mathrm{r}_{2 \mathrm{y} 3}$ which meant that $29.10 \%$ increase in student achievement can be done by variations in the score of the use of information and communication technology with a simple linear regression equation $\mathrm{Y}=73,353+0,572 \mathrm{X}_{3}$, which meant that if the score for the use of information and communication technology was increased in one unit, the learning achievement score will also increase by 0.72 at a constant 73.353. Furthermore, based on the results of the path analysis calculation between $\mathrm{Y}$ and $\mathrm{X}_{3}$ obtained for the value of $\mathrm{P}_{\mathrm{y} 3}=0.398$, which means it was greater than 0.05 , it can be concluded that the path coefficient between $\mathrm{Y}$ and $\mathrm{X}_{3}$ was significant.

Fourth, there was a positive and significant effect between the method of reward and punishment, teacher readiness, and the use of information and communication technology together to increase student achievement, indicated by the correlation coefficient $r_{\mathrm{y} . x 123}$ of 0.604 and the closeness of the relationship indicated by the coefficient of determination $\left(r_{\mathrm{y} . \times 123}\right)^{2}$ of 0.364 which meant that by $36.70 \%$ that the increase in student achievement can be done by variations in the score of the reward and punishment method, teacher readiness and the use of information and communication technology together with the form of multiple linear regression equation $\mathrm{Y}=$ $\mathrm{Y}=66,066+0.161 \mathrm{X}_{1}+0.062 \mathrm{X}_{2}+0.422 \mathrm{X}_{3}$. That was, if the reward and punishment method score, teacher readiness, and the use of information and communication technology were jointly increased by one unit. The student achievement score will increase by $(0.161+0.062+0.422)=0.645$ at a constant 66.066. Furthermore, based on the results of the path analysis calculation between $\mathrm{Y}$ and $\mathrm{X}_{123}$, the value of $\mathrm{P}_{\mathrm{yx123}}=1.649$, which meant greater than 0.05. It can be concluded that the path coefficient between $\mathrm{Y}$ and $\mathrm{X}_{123}$ was significant.

\section{Reward and punishment method on learning achievement}

The reward and punishment method was better and more intensely used by teachers. The better student learning achievement will be. The results found were in line with research by Amiruddin (2020), Yana (2016), Aan (2019), Lestari (2019), and Manoppo (2016), which stated that the reward and punishment method used by teachers affected student achievement.

The effect and relationship between the reward and punishment method on increasing student achievement was a form of strategy from the teacher to increase student motivation, which impacts student achievement. Teachers can carry out activities to meet the need for rewards in learning by providing rewards and punishments. Giving reward and punishment in learning had implications; 
namely, students were recognized as unique individuals who had certain abilities and characteristics that could be appreciated. Giving rewards was a positive response, while the punishment was a negative response, both of which had the same goal, namely wanting to change children's behavior in a better direction as learning motivation to improve learning outcomes (Djamarah, 2000).

Giving rewards was a form of positive reinforcement that will give birth to students' enthusiasm in learning so that a great effort arose and made the learning process effective so that it will affect student learning achievement. Meanwhile, the punishment, which was defined as punishment, was not detrimental to students but rather positively provided punishment if students violated the provisions in the learning process (Lestari, 2019).

\section{Teacher readiness for learning achievement}

The readiness of a good teacher will also improve student learning achievement. The results found were in line with Ngaifah (2020) and Sari (2008) research, which stated that there was a positive and significant effect on teacher readiness on student learning outcomes.

There was a strong relationship or effect between teacher readiness in teaching and student achievement. Efforts to improve the quality of teacher readiness required efficiency and accuracy in choosing strategies in the learning process. So it was appropriate for an educator to have global awareness in developing knowledge, skills, innovation, and technology literacy. Psychological teacher readiness refers to educational activities formulating learning objectives and implementing the learning process. Suppose the readiness of teachers of morals in teaching was always conducive, effective, and efficient. In that case, student learning achievement will increase and become even better, which of course will increase the competitiveness of student achievement, which was more competitive, both academic achievement shown by the development of students' cognitive abilities, as well as Non-academic achievement as a result of the development of students' abilities in the affective and psychomotor shutters.

Teachers should further improve teacher readiness by participating in training organized by the government and in schools to add experience, improve teaching skills, master learning methods and models and implement lesson plans (RPP), and motivate student learning so that the learning outcomes obtained are more optimal (Ngaifah, 2020).

\section{Utilization of information and communication technology on learning achievement}

The better and more intensive use of information and communication technology was used by teachers. The better student learning achievement will be. The results found were in line with Ariyani (2014) and Desmaniar (2020) research, which stated that information and communication technology affect student learning outcomes.

There was an effect from the use of information and communication technology on student learning achievement, that if a teacher prioritizes his professionalism, the teacher must be able to open up and be wise, and responsive to be able to master scientific products well by utilizing information and communication technology to support the teaching and learning process activities. Therefore, teachers were required to understand the competencies within themselves and then try to upgrade their competencies both independently and through joint activities. Creative and innovative teachers in the 4.0 era were teachers who were able to master the technology so that they were able to deliver students to be smart, independent, creative, and have global competitiveness competencies to achieve academic and non-academic achievements.

\section{The reward and punishment, teacher readiness, and the use of information and communication technology on student achievement}

The use of good and intense reward and punishment methods, good teacher readiness, and good and intense use of information and communication technology will result in better student learning achievement. The results found were in line with the research presented separately above. One of the duties of a teacher was to realize students who excelled in academic and non-academic. The student's 
achievement was interpreted that students must master science, be smart in innovation and creativity, understand universal values, discipline, initiative in solving problems, and have an entrepreneurial mentality. So to create this generation, a teacher must be able to train students' attitudes in carrying out the learning process. The reward and punishment method proved that the seriousness of student learning was increasing so that the achievement results given were quite good. Likewise in terms of teacher readiness in teaching will determine the quality of the learning process, which will ultimately affect student learning achievement. What was meant in the research readiness includes: physical condition, mental condition, emotional, needs such as learning, knowledge, while learning achievement was the result of the real effort measured to meet instructional needs.

Furthermore, in the context of the use of information and communication technology, the use of ICT was done by teachers both in planning, processing and evaluating learning which has the impact of facilitating the learning process so that learning was more interesting for students and for schools to improve the image or quality of schools (Destiyani, 2019). Conditions like this were actually the main important, and essential factors for achieving the effectiveness of achieving learning objectives. Technology was able to generate and build positive emotions in teaching and learning activities between teachers and students so that students' academic and non-academic achievements can be honed optimally. Thus, if all of the components in these variables can be improved and developed, it will make student learning achievements higher and better.

\section{CONCLUSION}

The study concluded that the method of reward and punishment, teacher readiness, and information and communication technology increased student achievement, both separately and together. Thus, teachers were expected to be able to use the reward and punishment method, prepare themselves, and utilize information and communication technology because it had a positive effect on student achievement.

\section{REFERENCES}

Abbas, N. A., Syah, I., \& Basri, M. (2017). Pengaruh Metode Reward and Punishment terhadap Motivasi Belajar Siswa Kelas XI IPS. PESAGI (Jurnal Pendidikan Dan Penelitian Sejarah), $5(6)$.

Aidillah, R. (2018). Pengaruh Reward and Punishment terhadap Minat Belajar Mata Pelajaran Sejarah Kebudayaan Islam Siswa MTS Pandanaran (Putri), Ngaglik, Sleman, Yogyakarta. Journal of Business Ethics, 14(3), 37-45.

Alawiyah, F. (2013). Peran guru dalam kurikulum 2013. Aspirasi: Jurnal Masalah-Masalah Sosial, $4(1), 65-74$.

Amirudin, A., Nurlaeli, A., \& Muzaki, I. A. (2020). Pengaruh Metode Reward and Punishment Terhadap Hasil Belajar Siswa Pada Bidang Studi Pendidikan Agama Islam (Studi Kasus Di Sdit Tahfizh Qur'an Al-Jabar Karawang). TARBAWY: Indonesian Journal of Islamic Education, 7(2), 140. https://ejournal.upi.edu/index.php/tarbawy/index

Ariyani, D. D., Hastuti, K. P., \& Alviawati, E. (2014). Pengaruh pemanfaatan teknologi informasi dan komunikasi (TIK) sebagai sumber belajar terhadap prestasi belajar siswa di smp negeri 15 banjarmasin. Jurnal Pendidikan Geografi, 1(3), 51-59.

Bali, M. M. E. I., Baharun, H., Madanibillah, A., Muali, C., Lukman, N. K. A., \& Bon, A. T. (2021). Innovative Learning Media Based on e-Learning in the New Normal Era. Proceedings of the 11th Annual International Conference on Industrial Engineering and Operations Management.

Buchari, A. (2018). Peran Guru Dalam Pengelolaan Pembelajaran. Jurnal Ilmiah Iqra', 12(2), 106. https://doi.org/10.30984/jii.v12i2.897

Desmaniar, I., Harapan, E., \& Kesumawati, N. (2020). Pengaruh Penggunaan Teknologi Informasi Dan Komunikasi Antar Pribadi Terhadap Hasil Belajar Siswa. CAHAYA PENDIDIKAN, 6(2), 79-93.

Destiyani, L. (2019). Pemanfaatan Teknologi Informasi Dan Komunikasi Oleh Guru PAI Dalam Proses Pembelajaran Di Sekolah: Studi Deskriptif Di SMP Ar-Rafi' Drajat Bandung Tahun 
2019. Universitas Pendidikan Indonesia.

Djamarah, S. B. (2000). Guru dan Anak Didik dalam Interaksi Edukatif. Rineka Cipta.

Goleman, D. (2004). Emotional Intelligence, Kecerdasan Emosional Mengapa EI Lebih Penting daripada IQ (T. Hermaya (ed.)). Gramedia Pustaka Utama.

Iptian, R. (2019). Pengaruh Kesiapan Guru Terhadap Pemanfaatan E-Learning. Jurnal Dinamika Manajemen Pendidikan, 3(2), 72. https://doi.org/10.26740/jdmp.v3n2.p72-77

Isnaini, Y. (2018). Penerapan Metode Reward dan Punishment Pada Pembelajaran Matematika Untuk Meningkatkan Motivasi dan Hasil Belajar Siswa Kelas V SD Negeri 3 Kotagajah Lampung Tengah Tahun Pelajaran 2017/2018. IAIN Metro.

Kurniawan, A. (2019). Pemanfaatan Teknologi Informasi dan Komunikasi (TIK) untuk Pembelajaran Di SMP Negeri 5 Ponorogo, Jawa Timur. Jurnal Teknodik, 23(1), 55. https://doi.org/10.32550/teknodik.voio.369

Lestari, A. (2019). Pengaruh Pemberian Reward Dan Punishment Terhadap Motivasi Belajar Dan Hasil Belajar Siswa Sekolah Dasar Islam Terpadu Iqra’ 2 Kota Bengkulu. Annizom, 4(1).

Manoppo, Y. K. (2016). Penerapan Metode Reward Dan Punishment Pada Mapel Pai Dalam Meningkatkan Prestasi Belajar Siswa Di Kelas I Sd Islam Al-Azhar 43 Gorontalo. Irfani, 12(1). http://journal.iaingorontalo.ac.id/index.php/ir/article/view/456/374

Minsih, M. (2018). Peran guru dalam pengelolaan kelas. Profesi Pendidikan Dasar, 5(1), $20-27$.

Muliastrini, N. K. E. (2019). Gerakan Literasi Sekolah (GLS) Sebagai Upaya Peningkatan Mutu Pendidikan. Prosiding Nasional, 35-45.

Nasution. (2009). Berbagai Pendekatan dalam Proses Belajar dan Mengajar. Bumi Aksara.

Ngaifah, N. (2020). Pengaruh Kesiapan Guru Dan Motivasi Belajar Terhadap Hasil Belajar PPKn Kelas IV Gugus RA Kartini Kecamatan Adiwerna Kabupaten Tegal.

Nilam, N. S. (2020). Pengaruh Pemberian Reward dan Punishment Terhadap Motivasi Belajar Peserta Didik pada Mata Pelajaran Akidah Akhlak Di MTs Al-Hidayah Batulappa. INSTITUT AGAMA ISLAM MUHAMMADIYAH SINJAI.

Ningsih, D. A. (2019). Guru Sebagai Manajer Kelas. Jurnal Pendidikan Dasar Dan Keguruan, 4(1), 23-32. https://doi.org/10.47435/jpdk.v4i1.91

Priatna, A. (2011). Pengaruh Penerapan teknologi Informasi dan komunikasi (TIK) Terhadap Prestasi Belajar Siswa Pada kelas Akselerasi. Jurnal Administrasi Pendidikan, 13(1).

Sari, L. P. (2008). Pengaruh Kesiapan Guru Terhadap Hasil Belajar Siswa Bidang Studi Matematika SMP Negeri Di Jember Kota Tahun Ajaran 2007/2008.

Shane, H. (1984). Arti Pendidikan bagi Masa Depan. Rajawali Pers.

Slameto. (2010). Belajar dan Faktor-faktor yang Mempengaruhi. Rineka Cipta.

Sutardi. (2020). Peningkatkan Aktivitas dan Hasil Belajar Siswa Melalui Pemberian Reward and Punishment (Point Plus/Minus) Pada Mata Pelajaran IPA Kelas VI di SDN 191/VIII Pematang Sapat, Kec. Rimbo Bujang. Jurnal Education of Batanghari, 2(12), 94-105.

Sutikno, M. S. (2007). Peran guru dalam membangkitkan motivasi belajar siswa. Jurnal Pendidikan, $1(1), 1-10$.

Syah, M. (2012). Psikologi Belajar. Raja Grafindo Persada.

Widiyono, A., Thoyyibah, D., Nasir, A. H. K., \& Hidayatullah, M. L. (2019). Pengaruh Reward dan Punishment terhadap Hasil Belajar Matematika Peserta Didik Kelas IV SDUT Bumi Kartini Jepara. Tunas Nusantara, 1(2).

Yana, D., \& Hajidin, I. S. (2016). Pemberian Reward dan Punishment Sebagai Upaya Meningkatkan Prestasi Siswa Kelas V di SDN 15 Lhokseumawe. Jurnal Ilmiah Pendidikan Guru Sekolah Dasar FKIP Unsyiah, 1(2), 11-18.

Yayan Alpian, Sri Wulan Anggraeni, Unika Wiharti, \& Nizmah Maratos Soleha. (2019). Pentingnya Pendidikan Bagi Manusia. Jurnal Buana Pengabdian, 1(1), 66-72. https://doi.org/10.36805/jurnalbuanapengabdian.v1i1.581

Yusri, Y. (2016). Pengaruh Penggunaan Media Teknologi Informasi dan Komunikasi (TIK) dengan Prestasi Belajar Bahasa Inggris Peserta Didik Kelas X di SMAN I Dekai Kabupaten Yahukimo. ILKOM Jurnal Ilmiah, 8(1), 49-56.

Zein, M. (2016). Peran guru dalam pengembangan pembelajaran. Jurnal Inspiratif Pendidikan, $5(2), 274-285$. 